\title{
Neuroprotective Effects of Ocimum basilicum Extract against Hydrogen Peroxide- Induced Oxidative Stress in SK-N-SH Neuroblastoma Cells
}

(Kesan Neuromelindungi Ekstrak Ocimum basilicum terhadap Tekanan Oksidatif yang Diaruh

Hidrogen Peroksida dalam Sel Neuroblastoma SK-N-SH)

\author{
Manali Haniti MOHD-ZAHID, JuRIYATI JALIL, KoK MENG ChAN \& NORAZRINA AZMI*
}

ABSTRACT

Neurodegenerative diseases such as Alzheimer's and Parkinson's disease are characterized by the progressive loss of neurons. One of the contributing factors for these diseases is oxidative stress, characterized by the imbalance of free radicals production and antioxidant defense mechanisms. In the present study, the neuroprotective effects of Ocimum basilicum var. thyrsiflora against hydrogen peroxide $\left(\mathrm{H}_{2} \mathrm{O}_{2}\right)$-induced oxidative stress in $\mathrm{SK}-\mathrm{N}$-SH neuroblastoma cells were evaluated. The exposure of $\mathrm{SK}-\mathrm{N}$-SH cells to $50 \mathrm{\mu M} \mathrm{H}_{2} \mathrm{O}_{2}$ for $24 \mathrm{~h}$ induced cytotoxicity and apoptosis as measured by cell viability and flow cytometry, respectively. Pretreatment with ethyl acetate (ObEA) fraction at 3.1-25 $\mu \mathrm{g} / \mathrm{mL}$ showed the highest protection against $\mathrm{H}_{2} \mathrm{O}_{2}$-induced cell death compared to other fractions and crude extract by increasing cell viability and reducing apoptosis. The evaluation of antioxidant capacity via 1, 1-diphenyl-2-picrylahydrazyl (DPPH) and ferric reducing/antioxidant power (FRAP) assays showed ObEA possessed the highest antioxidative properties. The intracellular reactive oxygen species (ROS) production of $\mathrm{H}_{2} \mathrm{O}_{2}$ in untreated cells increased by 2.39-fold compared to the control and was significantly attenuated by the $2 \mathrm{~h}$ pre-treatment of $\mathrm{O}$. basilicum $(\mathrm{p}<0.05)$. The reduction in intracellular superoxide dismutase ( $\mathrm{SOD}$ ) induced by $\mathrm{H}_{2} \mathrm{O}_{2}$ was also abrogated by the pretreatment of $\mathrm{O}$. basilicum. These findings suggested that $\mathrm{O}$. basilicum is potentially neuroprotective against oxidative damage in neuronal cells by scavenging free radicals, restoring SOD activities and eventually prevent cell death.

Keywords: Antioxidant; neuroprotective; Ocimum basilicum; rosmarinic acid

ABSTRAK

Penyakit kemerosotan saraf seperti Alzheimer dan Parkinson dicirikan oleh kehilangan neuron secara progresif. Salah satu faktor penyumbang penyakit ini ialah tekanan oksidatif, yang dicirikan oleh ketidakseimbangan antara penghasilan radikal bebas dan mekanisme pertahanan antioksidan. Dalam kajian ini, kesan neuromelindungi Ocimum basilicum var. thyrsiflora terhadap tekanan oksidatif yang diaruh hidrogen peroksida $\left(\mathrm{H}_{2} \mathrm{O}_{2}\right)$ dalam sel neuroblastoma SK-N$\mathrm{SH}$ telah dinilai. Pendedahan sel SK-N-SH terhadap $50 \mu \mathrm{M} \mathrm{H}_{2} \mathrm{O}_{2}$ selama 24 jam telah menyebabkan sitotoksik dan apoptosis yang masing-masing diukur melalui kebolehhidupan sel dan aliran sitometri. Pra-rawatan dengan fraksi etil asetat (ObEA) pada 3.1-25 $\mathrm{g} / \mathrm{mL}$ menunjukkan kesan perlindungan tertinggi terhadap kematian sel yang diaruh $\mathrm{H}_{2} \mathrm{O}_{2}$ berbanding fraksi lain dan ekstrak mentah dengan meningkatkan kebolehhidupan sel dan mengurangkan apoptosis. Penilaian kapasiti antioksidan melalui asai difenil-pikrilhidrazil (DPPH) dan asai kuasa antioksidan penurunan ferik (FRAP) menunjukkan ObEA mempunyai ciri antioksidan tertinggi. Pengeluaran spesies oksigen reaktif (ROS) intrasel dalam sel yang hanya dirawat $\mathrm{H}_{2} \mathrm{O}_{2}$ meningkat sebanyak 3.29 kali ganda berbanding dengan sel kawalan dan dilemahkan secara signifikan oleh 2 jam pra-rawatan $\mathrm{O}$. basilicum $(\mathrm{p}<0.05)$. Pengurangan superoksida dismutase $($ SOD) intrasel yang disebabkan oleh $\mathrm{H}_{2} \mathrm{O}_{2}$ juga turut dilemahkan oleh pra-rawatan O. basilicum. Keputusan kajian ini mencadangkan bahawa O. basilicum berpotensi berfungsi sebagai agen neuromelindungi terhadap kerosakan oksidatif dalam sel-sel neuron dengan merencatkan radikal bebas, memulihkan aktiviti SOD dan akhirnya menghalang kematian sel neuron.

Kata kunci: Antioksidan; asid rosmarinik; neuromelindungi; Ocimum basilicum

\section{INTRODUCTION}

Neurodegenerative disease is characterized by the progressive loss of neurons. One of the known causes for the disease is oxidative stress due to the imbalance between free radical production and antioxidant defence systems. Reactive oxygen species (ROS) induce loss of cellular membrane integrity and some protein functions including superoxide dismutase (SOD) (Avery 2011). Furthermore, neurons are susceptible to the free radicals due to high consumption of oxygen (Steinbrenner \& Sies 2013). Besides having synthetic drugs, the potential of natural sources as neuroprotective agent for neurodegenerative 
diseases has gained huge attention among researchers. For instance, plants with potent antioxidant activities such as Centella asiatica, Gingko biloba and Panax ginseng have been explored for their neuroprotective potential (Kumar \& Khanum 2012).

Ocimum basilicum or commonly known as sweet basil belongs to the Lamiaceae family. Modern pharmacological studies have reported some therapeutic potential showed by O. basilicum such as antioxidant (Kaurinovic et al. 2011; Kwee \& Niemeyer 2011; Patil et al. 2011; Rameshrad et al. 2015), antiinflammatory (Rameshrad et al. 2015), anticancer (Kathirvel \& Ravi 2012), antimicrobial (Srivastava et al. 2014a) and neuroprotective activities (Bora et al. 2011; Koutroumanidou et al. 2013). Rosmarinic acid is reported as the major bioactive compound in $O$. basilicum which possesses antioxidant properties (Jayasinghe et al. 2003; Srivastava et al. 2014b). However, the majority of antioxidative capacity of $O$. basilicum has been previously reported based on the direct interaction of the plant/oil extract with chemical reagents such as in DPPH and FRAP assays and not via bioassay studies. In addition, there is only a limited number of studies which have been documented on the antioxidant and neuroprotective effects of the O. basilicum extract compared to the other Ocimum species i.e. Ocimum sanctum.

$O$. basilicum var. thyrsiflora is one of the O. basilicum cultivars and it is known as Thai basil. It has been widely used in Asian culinary and traditional remedies. To the extent of our knowledge, there has been no reported in vitro study on this plant for the neuroprotective effects particularly via antioxidant mechanism. Thus, this study aimed to evaluate the neuroprotective effects of $O$. basilicum var. thyrsiflora against oxidative stress induced by $\mathrm{H}_{2} \mathrm{O}_{2}$ in SK-N-SH neuroblastoma cells. SK-N-SH cell is a suitable cell model to be used for neuroprotective studies as it shows neuronal phenotype with expression of numerous neurochemical markers (Jayaraj et al. 2013).

\section{MATERIALS AND METHODS}

\section{PREPARATION OF PLANT MATERIALS}

Ocimum basilicum var. thyrsiflora plants were obtained from local plantation in Gombak, Kuala Lumpur and a voucher specimen (HF100) was deposited at the Herbarium UKM Bangi. The leaves were dried and extracted with $80 \%$ ethanol at room temperature for 3 days and then filtered using Whatman No 1 filter paper. The extraction and filtration were repeated for 3 times. The filtrate was collected and concentrated under reduced pressure using a rotary evaporator. The extract was freeze-dried to get the crude extract $(\mathrm{ObCE})$ and stored at $4^{\circ} \mathrm{C}$ until further used. To prepare the fractions of $O$. basilicum, ObCE was macerated and sonicated in hexane solvent for $3 \mathrm{~h}$ at each cycle and filtered using Whatman No 1 filter paper. The extraction was repeated until clear solution was obtained showing that no more non-polar compounds being extracted. The filtrate was collected and concentrated under reduced pressure using a rotary evaporator to obtain the hexane fraction (ObHex). ObHex was stored at $4^{\circ} \mathrm{C}$ until further used. Meanwhile, the residue from $\mathrm{ObHex}$ was subsequently extracted with ethyl acetate solvent by using the same procedure to obtain the ethyl acetate fraction (ObEA). The last residue was known as ethanol fraction $(\mathrm{OBEtOH})$.

\section{DETERMINATION OF TOTAL PHENOLIC CONTENT USING FOLIN-CIOCALTEU METHOD (FC)}

Total phenolic content was determined using FC method adapted to 96-well plate as described by Zongo et al. (2010) with minor modifications. Briefly, $100 \mu \mathrm{L}$ of FC reagent $(10 \% \mathrm{v} / \mathrm{v})$ was added into $20 \mu \mathrm{L}$ of samples (ObCE, ObHex, ObEA and ObEtOH) dissolved in DMSO $(100 \mu \mathrm{g} / \mathrm{mL})$. After $5 \mathrm{~min}$ incubation, $80 \mu \mathrm{L}$ of sodium carbonate $(75 \mathrm{~g} / \mathrm{L})$ was added to each well. The 96-well plate was slightly shaken and incubated for $30 \mathrm{~min}$ at room temperature in the darkness. The absorbance was measured at $735 \mathrm{~nm}$ using microplate reader. Gallic acid was used as standard and total phenolic content was expressed as gallic acid equivalent per gram of sample based on equation of gallic acid calibration curve $\mathrm{Y}=0.0047 \mathrm{X}\left(\mathrm{R}^{2}=0.9992\right)$ where $\mathrm{Y}$ is the absorbance values and $\mathrm{X}$ is the gallic acid concentration.

\section{QUANTIFICATION OF ROSMARINIC ACID CONTENT IN $O$. BASILICUM BY HPLC ANALYSIS}

Chromatographic analysis was performed using High Performance Liquid Chromatography Prominence Shimadzu (HPLC Shimadzu LC-20AT) equipped with quaternary pump, diode array detector (DAD), autosampler, thermostated column oven, degasser and LC Solutions software. Separations were carried out on a SunFire C18 (5 $\mu \mathrm{m}, 4.6 \times 50 \mathrm{~mm}$ ) column.

The separation was conducted according to Srivastava et al. (2014). In summary, deionised water $+0.1 \%$ orthophosporic acid and methanol (HPLC grade) $+0.1 \%$ orthophosporic acid were used as mobile phase A and mobile phase B, respectively, by following the gradient program as follows: $0-2 \mathrm{~min}, 0 \% \mathrm{~B}$ (isocratic), $2-5 \mathrm{~min}, 40 \% \mathrm{~B}$ (linear gradient), 5-10 min, 50\% B (linear gradient), 10$18 \mathrm{~min}, 50 \% \mathrm{~B}$ (isocratic), 18-23 min, 40\% B (decreasing gradient), 23-25 $\mathrm{min}, 0 \% \mathrm{~B}$ (equilibration). The flow rate of the elution was $1.0 \mathrm{~mL} / \mathrm{min}$. The column was maintained at $25^{\circ} \mathrm{C}$ throughout the analysis. The detection wavelength was set at $280 \mathrm{~nm}$ with an injection volume of $20 \mu \mathrm{L}$. Linear standard calibration curve of rosmarinic acid (0.2$1.0 \mathrm{mg} / \mathrm{mL}$ ) were plotted to obtain unknown concentration of rosmarinic acid in $O$. basilicum. The validation of HPLC was carried out by determination of linearity, precision, limit of quantification (LOQ), and limit of detection (LOD).

\section{DPPH RADICAL SCAVENGING ACTIVITY ASSAY}

The determination of antioxidant activity of $O$. basilicum and its major phenolic compound, rosmarinic acid were 
carried out using DPPH scavenging assay adapted to 96well plate described by Zongo et al. (2010) with minor modifications. Graded concentrations of samples were prepared ranging from 1.953 to $1000 \mu \mathrm{g} / \mathrm{mL}$ obtained by two-fold dilutions. Briefly, $100 \mu \mathrm{L}$ of DPPH solution (10\% dissolved in DMSO) was added to the $100 \mu \mathrm{L}$ of samples and the mixture was allowed to stand at room temperature in the dark for $60 \mathrm{~min}$. The absorbance was read at 540 $\mathrm{nm}$ using microplate reader. Gallic acid and quercetin were used as standard reference. The scavenging activity of DPPH radical was calculated as:

$$
\% \mathrm{RSA}=\left[1-\left(\mathrm{A}_{1}-\mathrm{A}_{2}\right) / \mathrm{A}_{0}\right] \times 100
$$

where $\mathrm{A}_{0}$ is the absorbance of control (without sample); $\mathrm{A}_{1}$ is the absorbance of sample; and $\mathrm{A}_{2}$ : Absorbance of sample (without DPPH radical).

The results were expressed as $\mathrm{IC}_{50}$ value (concentration at which $50 \%$ inhibition of DPPH radical) which were obtained from the relationship curves of scavenging activities (\%) versus linear range of sample concentrations. The antioxidant activity index (AAI) was measured as; $\mathrm{AAI}=[\mathrm{DPPH}](\mu \mathrm{g} / \mathrm{mL}) / \mathrm{IC}_{50}(\mu \mathrm{g} / \mathrm{mL})$ in which $[\mathrm{DPPH}]$ is the final concentration of DPPH radicals.

\section{FERRIC REDUCING/ANTIOXIDANT POWER (FRAP) ASSAY}

FRAP assay was conducted according to Yang et al. (2011) with minor modifications. All solutions were freshly prepared. Briefly, $270 \mu \mathrm{L}$ of FRAP reagent consisting of $300 \mathrm{mM}$ acetate buffer (pH3.6), 10 mM 2,4,6-tripyridyl-striazine (TPTZ) (in $40 \mathrm{mM} \mathrm{HCl}$ ) and $20 \mathrm{mM}$ ferric chloride at $10: 1: 1(\mathrm{v} / \mathrm{v} / \mathrm{v})$ was added to the $30 \mu \mathrm{L}$ of sample $(1$ $\mathrm{mg} / \mathrm{mL}$ dissolved in DMSO) and warmed at $37^{\circ} \mathrm{C}$ for 4 min. Gallic acid and quercetin were used as standard reference. The absorbance was read at $593 \mathrm{~nm}$. Different concentrations of trolox $(0.195$ to $200 \mu \mathrm{g} / \mathrm{mL})$ were used to plot standard curve and results obtained were expressed as FRAP value (mg trolox/ mg sample dry weight).

\section{CELL CULTURE AND TREATMENT}

SK-N-SH neuroblastoma cells were purchased from the American Type Culture Collection (ATCC, Rockville, MD, USA) and cultured in Eagle Minimum Essential Medium (EMEM; Gibco, USA) enriched with $10 \%$ fetal bovine serum (FBS; Tico Europe) and 1\% penicillin-streptomycin (Nacalai Tesque, Japan). Cells were grown in $75 \mathrm{~cm}^{2}$ tissue culture flask and kept at $37^{\circ} \mathrm{C}$ in $5 \% \mathrm{CO}_{2}$. The medium was changed every 2 days and cells were passaged once they reached $80 \%$ confluence.

\section{MTT CELL VIABILITY ASSAY}

The effect of the sample treatment on SK-N-SH cells viability was measured using MTT (3-(4,5-Dimethylthiazol2-yl)-2,5-Diphenyltetrazolium Bromide) assay. SK-N-SH cells were plated $\left(5 \times 10^{4}\right.$ cells/well) into 96 -well plate and incubated overnight as described previously. Cells were treated with $O$. basilicum, rosmarinic acid (Sigma, USA) and N-Acetyl-L-cysteine (NAC; Sigma, USA). NAC is a potent antioxidant to combat oxidative stress and has been demonstrated to display neuroprotective activities (Naziroğlu et al. 2014). After treatment, MTT reagent (5 mg/ $\mathrm{mL}$ ) was added to each well and incubated for $4 \mathrm{~h}$ at $37^{\circ} \mathrm{C}$. Then, culture medium containing MTT was discarded and DMSO was added to solubilize the purple formazan. After 15 min of incubation, the absorbance was measured at 517 nm using ELISA microplate reader (Tecan, Switzerland). Cell viability was expressed as the percentage relative to untreated cells.

\section{APOPTOSIS ASSAY BY ANNEXIN V-FITC/PI STAINING}

The mode of cell death induced by $\mathrm{H}_{2} \mathrm{O}_{2}$ was assessed by flow cytometry using Annexin V-FITC/PI assay (BD Bioscience, USA). SK-N-SH cells were pretreated with various concentration of $\mathrm{ObCE}, \mathrm{ObEA}, \mathrm{ObEtOH}$, rosmarinic acid and NAC for $2 \mathrm{~h}$ prior to $50 \mu \mathrm{M} \mathrm{H}_{2} \mathrm{O}_{2}$ for $24 \mathrm{~h}$. After treatment, cells were harvested then washed with chilled PBS before suspended in Annexin binding buffer and incubated with fluorescence isothiocyanate (FITC)-conjugated Annexin V 15 min and another 5 min with propidium iodide (PI). Then, $400 \mu \mathrm{L}$ of ABB was added to the stained cells and the cell suspension was transferred to a polystyrene round-bottom tube prior to analysis with FACSCanto II flow cytometer.

\section{INTRACELLULAR ROS MEASUREMENT}

Intracellular ROS level was assessed by dichloro-dihydrofluorescein diacetate (DCFH-DA) labeling assay as previously described by Chan et al. (2010). Treated cells were harvested and washed with chilled PBS. The cell pellet was suspended in $1 \mathrm{~mL}$ pre-warmed serum-free medium and then $1 \mu \mathrm{l}$ of $10 \mathrm{mM}$ DCFH-DA (Life Technologies, USA) was added into the suspension. Staining was performed in dark at $37^{\circ} \mathrm{C}$ followed by centrifugation at $220 \times \mathrm{g}$ for $5 \mathrm{~min}$. The cells were washed with $1 \mathrm{~mL}$ chilled PBS (2 times) and the supernatant was discarded. Afterwards, $500 \mu \mathrm{L}$ of chilled PBS was added to resuspend the pellets. The stained cell suspension was transferred to polystyrene round-bottom tube and analyzed using BD FACSCanto II Flow Cytometer.

\section{INTRACELLULAR SUPEROXIDE DISMUTASE (SOD) ACTIVITY ASSESSMENT}

The intracellular SOD activity was measured spectrophotometrically according to the instruction given in the SOD assay kit (Abcam, USA). Briefly, treated cells were harvested and then washed with chilled PBS at $250 \times \mathrm{g}$ $\left(4^{\circ} \mathrm{C}\right)$ for $10 \mathrm{~min}$ and supernatant was discarded. Then, cell pellets were sonicated in chilled PBS and spun at $1500 \times \mathrm{g}$ for $10 \mathrm{~min}$. Supernatant were collected and then spinned at $10,000 \times \mathrm{g}$ for $15 \mathrm{~min}$. Later, the supernatant was collected and used to measure SOD activity at $450 \mathrm{~nm}$ by using microplate reader (Tecan, Switzerland). 


\section{STATISTICAL ANALYSIS}

All data are presented as mean \pm standard error of the mean (SEM). A one-way analysis of variance (ANOVA) followed by post-Dunnett's analysis using GraphPad Prism 5 Software was performed and values of $p<0.05$ were considered significant.

\section{RESULTS AND DISCUSSION}

\section{TOTAL PHENOLIC CONTENT}

ObEtOH contained the highest polyphenol content which was $125.80 \mathrm{mg} / \mathrm{g}$ gallic acid equivalent, followed by ObEA (100.97 mg/g GAE), ObCE (88.32 mg/g GAE) and ObHex (50.61 mg/g GAE) which may account for the observed biological effects in the present study. However, the total phenolic contents among the crude extract and fractions were not statistically different. Previously, Bora et al. (2011) also have reported that $O$. basilicum contains phenolic, flavonoids and tannins which demonstrated neuroprotective effects in ischemia and reperfusioninduced cerebral damage in mice.

\section{HPLC ANALYSIS}

HPLC chromatogram of $O$. basilicum exhibited the peak of rosmarinic acid corresponding to the retention time at $15.01 \pm 0.02 \mathrm{~min}$ (Figure 1). The quantification of rosmarinic acid in the $O$. basilicum showed $\mathrm{ObEtOH}$ contained the highest amount of rosmarinic acid $(37.81 \pm 1.57 \mu \mathrm{g} / \mathrm{mL})$ followed by ObCE $(37.02 \pm 1.65 \mu \mathrm{g} /$ $\mathrm{mL}), \operatorname{ObEA}(33.66 \pm 0.75 \mu \mathrm{g} / \mathrm{mL})$ and ObHex $(9.61 \pm 0.21$ $\mu \mathrm{g} / \mathrm{mL})$. It can be suggested that the extraction yield (rosmarinic acid) increases with increasing polarity of the solvent used in extraction. It also can be found that the content of rosmarinic acid in ObEtOH is slightly high than the crude extract $(\mathrm{ObCE})$. This result indicates that increasing polarity of the solvent in sequential fractionation enhances rosmarinic acid concentration. The calibration curve plotted for the rosmarinic acid standard over the concentration range of $200-1000 \mu \mathrm{g} / \mathrm{mL}$ showed a correlation coefficient $\left(\mathrm{R}^{2}\right)$ of 0.995 . The relative standard deviations ( $\%$ RSD) were measured to confirm the reproducibility of the results. The $\%$ RSD values for intra-day of the mean retention time and mean area under the peak were $0.358 \%$ and $3.256 \%$, respectively, whereas the $\%$ RSD values for inter-day of the mean retention time and mean area under the peak were $0.274 \%$ and $3.652 \%$, respectively. The LOD and LOQ of rosmarinic acid were found to be 2.258 and $6.843 \mu \mathrm{g} / \mathrm{mL}$, respectively.

Our HPLC analysis confirmed the presence of rosmarinic acid compound which has been reported as the major bioactive compound in O. basilicum (Lee 2010; Srivastava et al. 2014; Zgorka et al. 2001). In accordance with the highest total phenolic content, ObEtOH also showed the highest rosmarinic acid concentration compared to the crude extract and other fractions.

\section{ANTIOXIDANT AND FREE RADICAL SCAVENGING ACTIVITIES OF O. BASILICUM}

In this study, we evaluated the antioxidant capacities of $O$. basilicum using DPPH and FRAP assays, the two widely used assays for evaluation of in vitro antioxidant activities (Alam et al. 2013). The hydroethanolic crude extract, fractions of $O$. basilicum and rosmarinic acid were tested for their free radical scavenging activity on DPPH using quercetin and gallic acid as standards. Based on the radical scavenging activity (\% RSA) regression curve obtained (data not shown), the $\mathrm{IC}_{50}$ for standards and samples were identified as $50 \%$ of inhibition concentration. ObEA showed free radical scavenging activity with the AAI of 0.32 (Table 1). Interestingly, rosmarinic acid showed efficient scavenging activity compared to the standard quercetin while gallic acid standard showed the highest AAI. However, the $\mathrm{IC}_{50}$ of $\mathrm{ObCE}, \mathrm{ObHex}$ and $\mathrm{ObEtOH}$ cannot be determined.

The FRAP values ranged from $0.67 \pm 0.06$ to $2.48 \pm 0.01$ $\mathrm{mg} / \mathrm{mg}$ (Table 1). Gallic acid showed the strongest antioxidant consistent with its highest antioxidant abilities in DPPH assay while ObEA showed the highest FRAP value compared to the crude extract and other fractions.

In both DPPH and FRAP assays, ObEA showed the highest antioxidant capacity compared to the crude extract and other fractions. This result showed that high phenolic content did not necessarily result in potent antioxidant activities. Our findings are in agreement with previous studies of Bhebhe et al. (2015), Chew et al. (2011) and Kasparavičienè et al. (2013) who reported that no

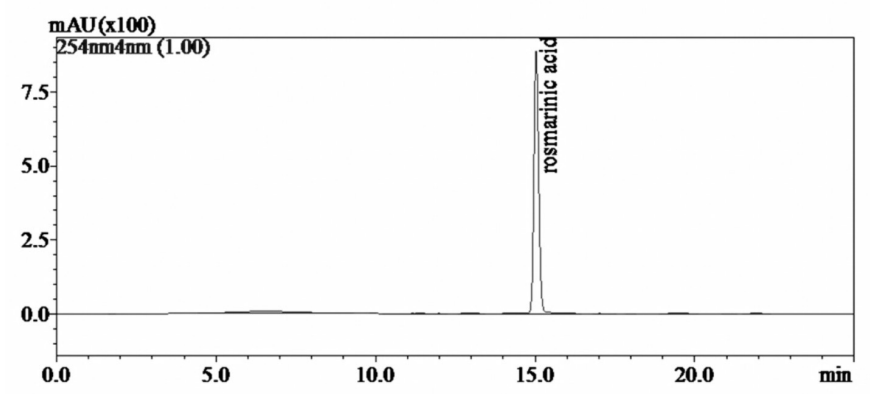

FIGURE 1. HPLC chromatogram of rosmarinic acid standard; the peak at retention time of $15.01 \pm 0.02 \mathrm{~min}$ 
TABLE 1 . Antioxidant activity of $O$. basilicum and rosmarinic acid.

Data are presented as mean $\pm \operatorname{SEM}(n=3)$

\begin{tabular}{lccc}
\hline \multirow{2}{*}{ Sample } & \multicolumn{2}{c}{ DPPH } & FRAP \\
\cline { 2 - 4 } & $\mathrm{IC}_{50}$ & AAI & Equivalent trolox amount $(\mathrm{mg} / \mathrm{mg})$ \\
\hline Quercetin & $23.87 \pm 5.17$ & 2.09 & $2.46 \pm 0.01$ \\
Gallic acid & $2.48 \pm 0.01$ & 13.32 & $2.48 \pm 0.01$ \\
Rosmarinic acid & $17.04 \pm 1.31$ & 2.93 & $2.21 \pm 0.03$ \\
ObCE & nd & nd & $1.24 \pm 0.03$ \\
ObHex & nd & nd & $0.67 \pm 0.06$ \\
ObEA & $156.74 \pm 6.93$ & 0.32 & $1.36 \pm 0.02$ \\
ObEtOH & nd & nd & $1.28 \pm 0.05$ \\
\hline
\end{tabular}

nd: not detectable

correlation has been noted between phenolic contents and antioxidant capacity. In contrast, a study conducted by Sultana et al. (2009) showed plants with higher total phenolic content exhibited greater antioxidant activity.

\section{PROTECTIVE EFFECTS OF O. BASILICUM ON $\mathrm{H}_{2} \mathrm{O}_{2}$-INDUCED NEURONAL DEATH}

High phenolic fractions of $O$. basilicum (ObEA, ObEtOH) and crude extract $(\mathrm{ObCE})$ were subjected for the in vitro study. The results showed that $\mathrm{H}_{2} \mathrm{O}_{2}$ reduced SK-N-SH cell viability in a dose-dependent manner after $24 \mathrm{~h}$ incubation (Figure 2(A)). It is well documented that $\mathrm{H}_{2} \mathrm{O}_{2}$ is widely used to induce oxidative stress in SK-N-SH cells (Choi et al. 2013; Ezoulin et al. 2008; Hu et al. 2012). At $50 \mu \mathrm{M}$ of $\mathrm{H}_{2} \mathrm{O}_{2}$, cell viability was reduced to $60.9 \%$ as compared to the control group. This concentration was therefore used in this study to induce oxidative stress. Pretreatment with $\mathrm{ObCE}, \mathrm{ObEA}, \mathrm{ObEtOH}$, rosmarinic acid and NAC $2 \mathrm{~h}$ prior
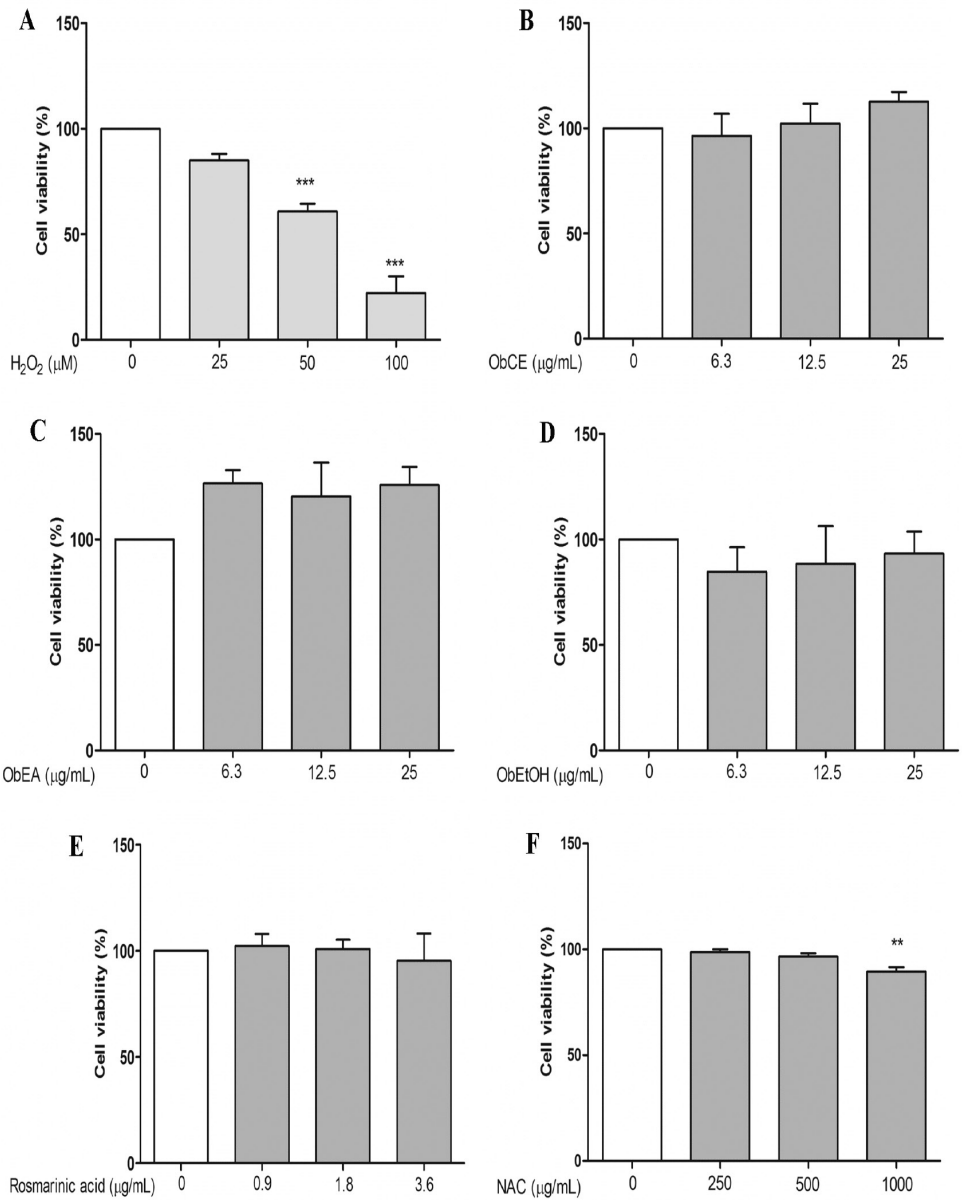

Data are presented as mean $\pm \operatorname{SEM}(n=3) . * * p<0.01, * * * p<0.001$ vs. control group

FIGURE 2. (A) Effect of $\mathrm{H}_{2} \mathrm{O}_{2}$ on SK-N-SH cell viability. Treatment with $O$. basilicum (B) ObCE, (C) ObEA, (D) $\mathrm{ObEtOH},(\mathrm{E})$ rosmarinic acid and (F) NAC did not cause cytotoxicity in SK-N-SH cells at all concentrations 
to $\mathrm{H}_{2} \mathrm{O}_{2}$-induced cytotoxicity were found to attenuate the effects of $\mathrm{H}_{2} \mathrm{O}_{2}$ and significantly increased cell viability (Figure 3). At all the tested concentrations, ObCE, ObEA, $\mathrm{ObEtOH}$, rosmarinic acid and NAC alone did not show any obvious toxicity on the viability of SK-N-SH cells (Figure 2(B-F)).

\section{EFFECTS OF $O$. BASILICUM $\mathrm{ON} \mathrm{H}_{2} \mathrm{O}_{2}$-INDUCED APOPTOSIS IN SK-N-SH CELLS}

The protective effects of $O$. basilicum, rosmarinic acid and NAC against $\mathrm{H}_{2} \mathrm{O}_{2}$-induced apoptosis were measured by flow cytometry. After exposure to $\mathrm{H}_{2} \mathrm{O}_{2}$ only for $24 \mathrm{~h}$, cells showed higher apoptotic event compared to necrotic event (Figure 4). The percentage of viable cells, apoptotic and necrotic cells at $50 \mathrm{MM} \mathrm{H}_{2} \mathrm{O}_{2}$ were $23.8 \pm 3.6 \%, 65.9 \pm 9.9 \%$ and $10.4 \pm 6.8 \%$, respectively. The percentage of viable and apoptotic cells showed a significant difference $(p<0.05)$ compared to the control but not the percentage of necrotic cells. Our results were in agreement with previous studies which reported that $\mathrm{H}_{2} \mathrm{O}_{2}$ induced apoptosis in several cell lines (Chen et al. 2016; Jin et al. 2013; Yu et al. 2016). Cells pretreated with ObEA and NAC for $2 \mathrm{~h}$ prior to the
$\mathrm{H}_{2} \mathrm{O}_{2}$ induction increased cell viability in dose-dependent manners. Pretreatment of cells with ObCE also showed a dose-dependent protective actions against $\mathrm{H}_{2} \mathrm{O}_{2}$-induced apoptosis up to $12.5 \mu \mathrm{g} / \mathrm{mL}$. However, cell viability of the cells pretreated with $\mathrm{ObEtOH}$ and rosmarinic acid did not increase.

It is interesting to note that the percentage of viable cells detected in Annexin V staining was lower compared to the MTT result. In fact, vast literature has been published on the effect of several phytochemicals and plant extracts on MTT assay which potentially reduced MTT in the absence of cells (Peng et al. 2005; Shoemaker et al. 2004). Similarly, Chan et al. (2006) has reported that there was a discrepancy between MTT results and acridine orange/propidium iodide (AO/PI) staining which suggested possible compound interaction with MTT.

\section{EFFECTS OF $O$. BASILICUM $\mathrm{ON} \mathrm{H}_{2} \mathrm{O}_{2}$-INDUCED PRODUCTION OF REACTIVE OXYGEN SPECIES (ROS)}

Intracellular ROS production was detected with 2,7'-dichlorofluorescein (DCF) diacetate. Cells treated with $50 \mu \mathrm{M} \mathrm{H}_{2} \mathrm{O}_{2}$ for $24 \mathrm{~h}$ showed a significant increase
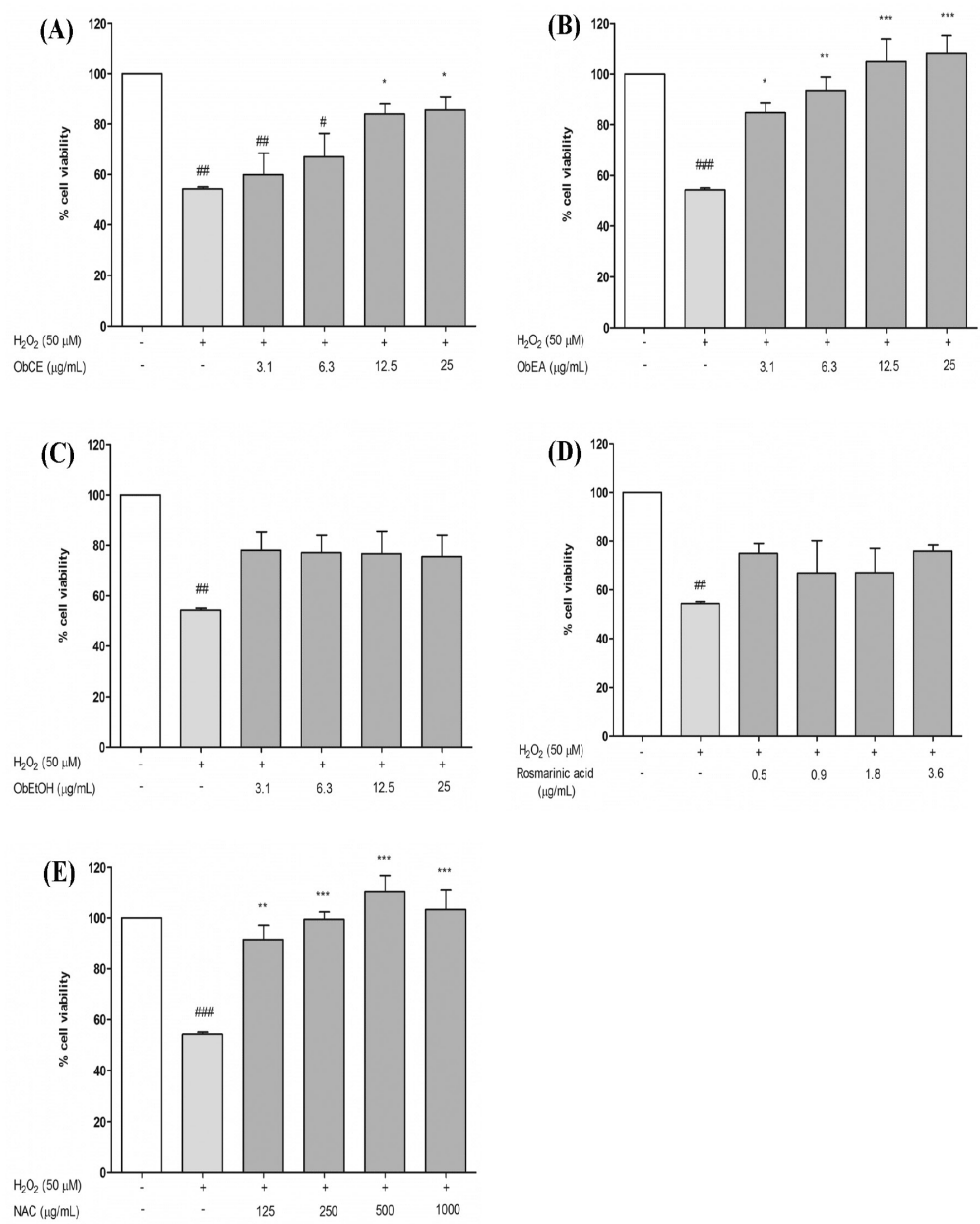

Data are presented as mean $\pm \operatorname{SEM}(n=3) .{ }^{\#} p<0.05,{ }^{\# \#} p<0.01,{ }^{\# \# \#} p<0.001$ vs. control, ${ }^{*} p<0.05{ }^{* *} p<0.01, * * * p<0.001$ vs. $\mathrm{H}_{2} \mathrm{O}_{2}$ untreated group

FIGURE 3. The protective effects of (A) ObCE, (B) ObEA, (C) ObEtOH, (D) rosmarinic acid and (E) NAC with indicated concentrations on $\mathrm{H}_{2} \mathrm{O}_{2}$-induced cytotoxicity in SK-N-SH cells as determined using MTT assay 

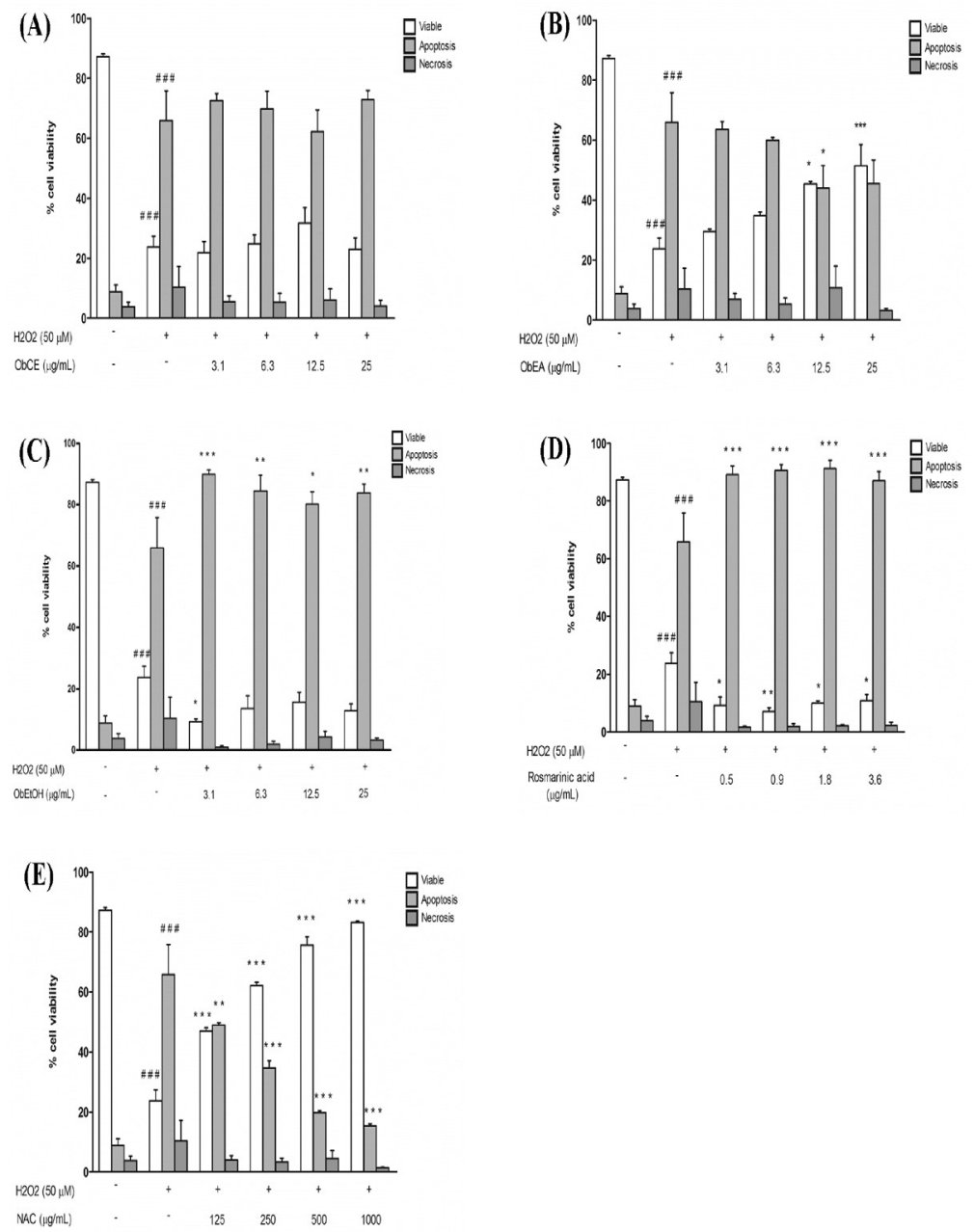

Data are presented as mean $\pm \operatorname{SEM}(n=3) .{ }^{\# \# \#} p<0.001$ vs. control, $* p<0.05 * * p<0.01, * * * p<0.001$ vs. $\mathrm{H}_{2} \mathrm{O}_{2}$ untreated group

FIGURE 4. The protective effects of (A) ObCE, (B) ObEA, (C) ObEtOH, (D) rosmarinic acid and (E) NAC with indicated concentrations on $\mathrm{H}_{2} \mathrm{O}_{2}$-induced cytotoxicity in SK-N-SH cells as determined using Annexin V-FITC/PI

in ROS levels 2.39-fold compared to control $(p<0.001)$ (Figure 5). However, cells pretreated with ObCE, ObEA, $\mathrm{ObEtOH}$, rosmarinic acid and NAC (Figure 6(A)-6(E)) significantly reduced the ROS levels compared to cells induced with $\mathrm{H}_{2} \mathrm{O}_{2}$ alone. Increase in ROS generation caused the imbalance redox state in cell and initiated the oxidative stress. Pretreatment with $O$. basilicum significantly reduced the elevated ROS levels caused by $\mathrm{H}_{2} \mathrm{O}_{2}$ treatment. Similar results were observed when cells were pretreated with rosmarinic acid and NAC. Pre-treatment of cells with lower concentrations of $O$. basilicum was enough to reduce the ROS accumulation approaching the control values. The inhibition of ROS accumulation by $O$. basilicum appears to protect the $\mathrm{SK}-\mathrm{N}-\mathrm{SH}$ cells from $\mathrm{H}_{2} \mathrm{O}_{2}$-induced cytotoxicity. These findings demonstrate that $O$. basilicum is a potent antioxidant, which might be due to ROS scavenging property of $O$. basilicum and eventually contribute to its neuroprotective effect. A previous study indicated that $O$. basilicum extract possessed protective effects on ischemia and reperfusion-induced cerebral damage and motor dysfunctions in mice through restoration of oxidative stress marker; glutathione (GSH) (Bora et al. 2011). Our data confirm that $O$. basilicum has antioxidant activity against $\mathrm{H}_{2} \mathrm{O}_{2}$-mediated intracellular ROS accumulation.

EFFECTS OF $O$. BASILICUM, ROSMARINIC ACID AND NAC ON SOD ACTIVITY IN SK-N-SH CELLS INDUCED WITH $\mathrm{H}_{2} \mathrm{O}_{2}$

Exposure of SK-N-SH cells to $50 \mu \mathrm{M} \mathrm{H}_{2} \mathrm{O}_{2}$ for $24 \mathrm{~h}$ reduced intracellular SOD level from $0.42 \pm 0.04 \mathrm{U} / \mathrm{mL}$ to $0.32 \pm 0.02 \mathrm{U} / \mathrm{mL}$. The $\mathrm{H}_{2} \mathrm{O}_{2}$-induced SOD depletion in SK-N-SH cells has been previously demonstrated in a few studies (Li et al. 2014; Zhang et al. 2017). Excessive superoxide can decrease the antioxidant enzyme activities which explain the reduction of SOD level in our study. This effect was mitigated by pretreatment with ObCE, ObEA, ObEtOH, rosmarinic acid and NAC (Figure 7(A)$7(\mathrm{E}))$. At the lowest concentration, pre-treatment of cells with $\mathrm{ObEtOH}$ prior to $\mathrm{H}_{2} \mathrm{O}_{2}$-induced SOD depletion showed the highest SOD activity showing that the optimal concentration of ObEtOH to trigger the SOD activity was $3.1 \mu \mathrm{g} / \mathrm{mL}$. 

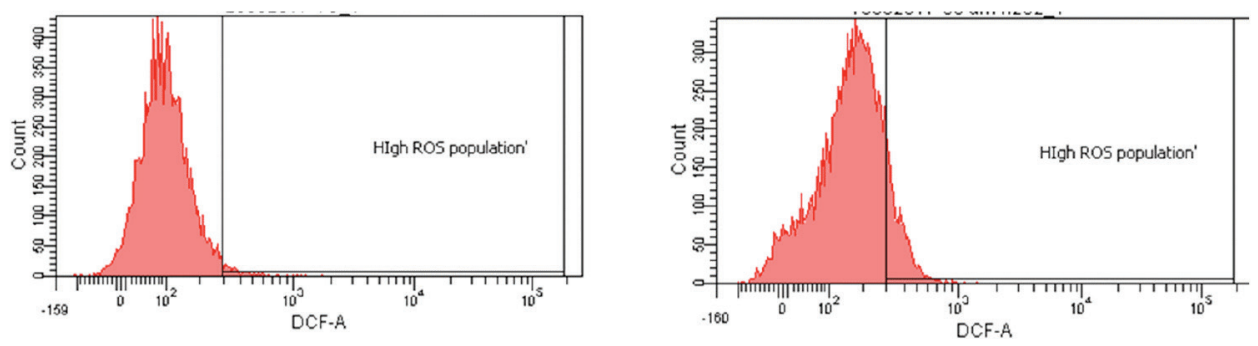

FIGURE 5. The chromatogram of DCF fluorescence (A) Untreated SK-N-SH cells,

(B) SK-N-SH cells treated with $50 \mu \mathrm{M} \mathrm{H}_{2} \mathrm{O}_{2}$ after $24 \mathrm{~h}$
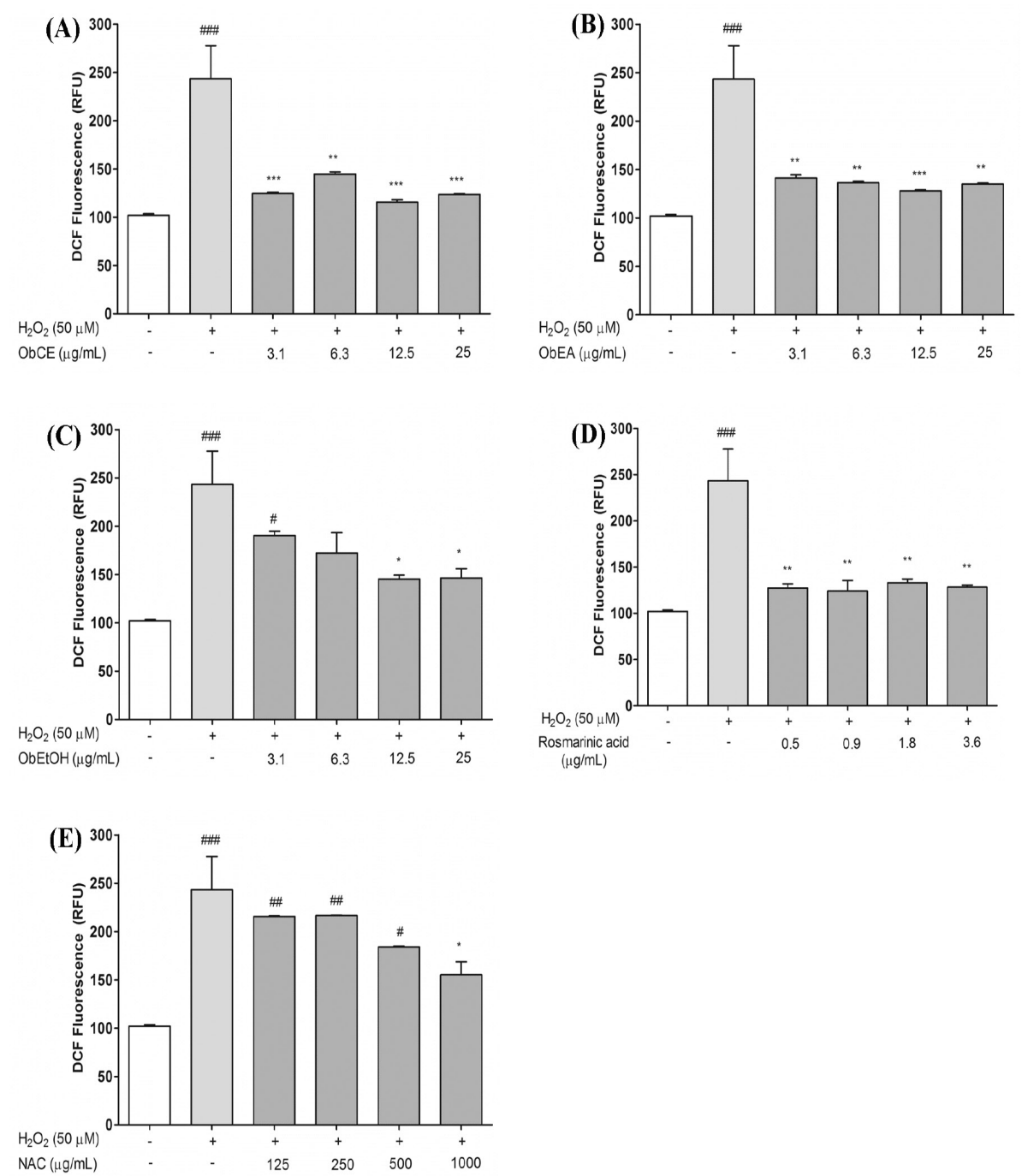

Data are presented as mean $\pm \operatorname{SEM}(n=3) .{ }^{*} p<0.05 .{ }^{\# \#} p<0.01,{ }^{\# \# \# p} p<0.001$ vs. control, ${ }^{*} p<0.05 * * p<0.01, * * * p<0.001$ vs. $\mathrm{H}_{2} \mathrm{O}_{2}$ untreated group

FIGURE 6. The protective effects of (A) ObCE, (B) ObEA, (C) ObEtOH, (D) rosmarinic acid and (E) NAC on $\mathrm{H}_{2} \mathrm{O}_{2}$-induced ROS production in SK-N-SH cells

Nevertheless, the SOD levels were higher than the control group, suggesting that $O$. basilicum up-regulated intracellular SOD levels. SOD is an endogenous antioxidant enzyme which helps to eliminate free radicals (Reiter 1995 ) in maintaining optimal cellular functions. SOD is known as the first line of defence which is responsible to dismutate superoxide radicals into hydrogen peroxide (less reactive species) which is then further converted to water and oxygen by catalase ( $\mathrm{Li}$ et al. 2016). Therefore, the observed effects with $O$. basilicum are suggestive of neuroprotection by ways of enhancing the activity of endogenous antioxidant enzyme. 

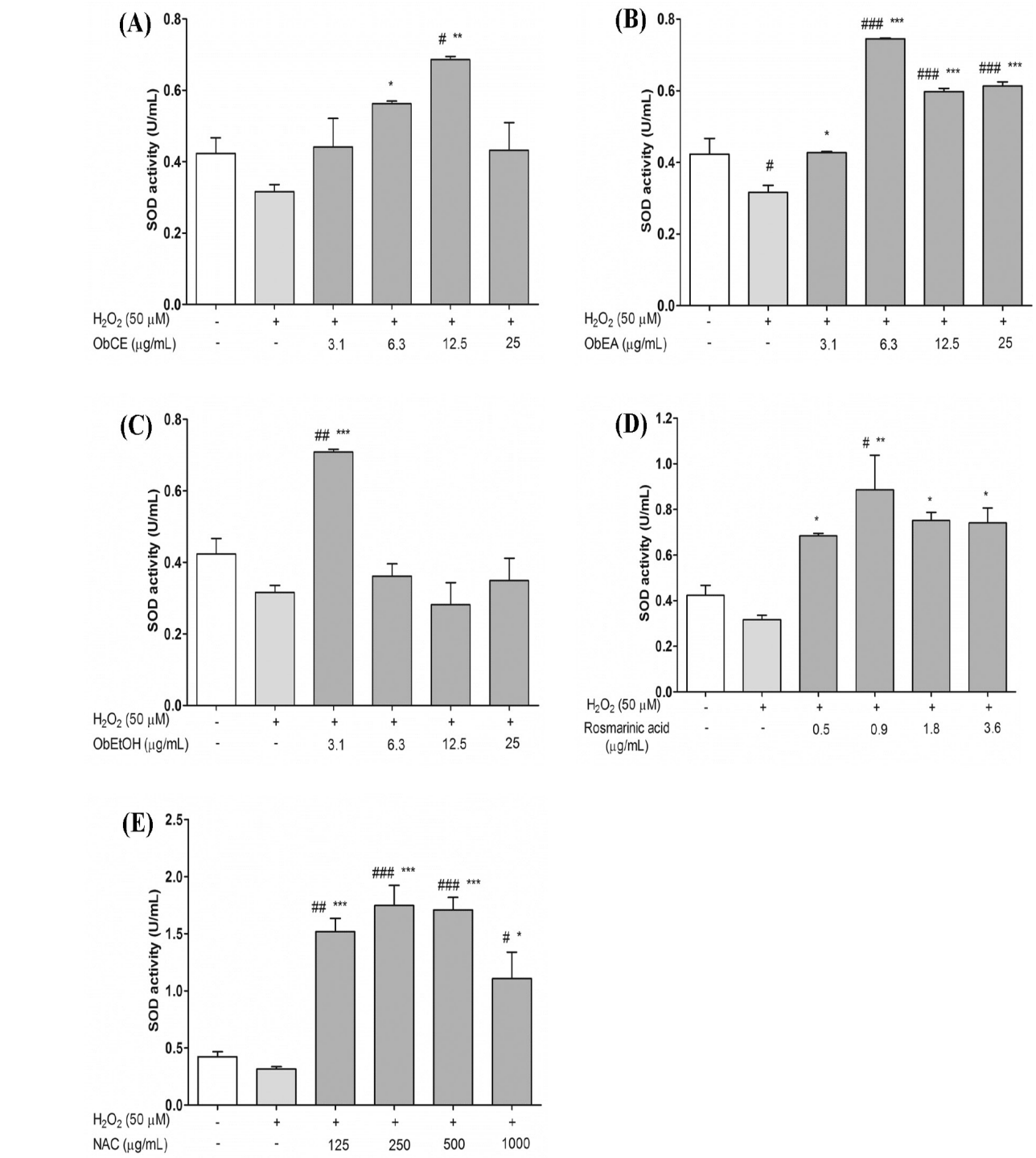

Data are presented as mean $\pm \operatorname{SEM}(n=3) .{ }^{*} p<0.05 .{ }^{* \# p} p<0.01,{ }^{* \#{ }^{*}} p<0.001$ vs. control, ${ }^{*} p<0.05 * * p<0.01$, ${ }^{* * *} p<0.001$ vs. $\mathrm{H}_{2} \mathrm{O}_{2}$ untreated group

FIGURE 7. The activity of SOD of (A) ObCE, (B) ObEA, (C) ObEtOH, (D) rosmarinic acid and (E) NAC on $\mathrm{H}_{2} \mathrm{O}_{2}$-induced in SK-N-SH cells

\section{CONCLUSION}

Our study showed that at molecular level, O. basilicum exerted neuroprotection against $\mathrm{H}_{2} \mathrm{O}_{2}$-induced cytotoxicity by lowering oxidative damage characterised by the reduction of intracellular ROS generation and restoration of intracellular SOD levels. Taken collectively, O. basilicum may directly act as a radical scavenger to eliminate ROS and eventually enhance intracellular SOD activity. These properties may explain its neuroprotective effects observed in our study which aided in protecting neuronal cells from $\mathrm{H}_{2} \mathrm{O}_{2}$-induced oxidative damage and could be potentially explored as a prevention modality of neurodegenerative diseases.

\section{ACKNOWLEDGEMENTS}

The authors would like to acknowledge the Ministry of Higher Education, Malaysia under Fundamental Research
Grant Scheme (Project Grant No. FRGS/2/2013/SKK03/ $\mathrm{UKM} / 02 / 1$ ) for the financial support.

\section{REFERENCES}

Alam, M.N., Bristi, N.J. \& Rafiquzzaman, M. 2013. Review on in vivo and in vitro methods evaluation of antioxidant activity. Saudi Pharmaceutical Journal 21(2): 143-152.

Avery, S.V. 2011. Molecular targets of oxidative stress. Biochem. J. 434(2): 201-210.

Bhebhe, M., Füller, T.N., Chipurura, B. \& Muchuweti, M. 2015. Effect of solvent type on total phenolic content and free radical scavenging activity of black tea and herbal infusions. Food Anal. Methods 4(9): 1060-1067.

Bora, K.S., Arora, S. \& Shri, R. 2011. Role of Ocimum basilicum L. in prevention of ischemia and reperfusion-induced cerebral damage, and motor dysfunctions in mice brain. $J$. Ethnopharmacol. 137(3): 1360-1365. 
Chan, K.M., Rajab, N.F., Ishak, M.H.A., Ali, A.M., Yusoff, K., Din, L.B. \& Inayat-Hussain, S.H. 2006. Goniothalamin induces apoptosis in vascular smooth muscle cells. ChemicoBiological Interactions 159(2): 129-140.

Chan, K.M., Rajab, N.F., Siegel, D., Din, L.B., Ross, D. \& InayatHussain, S.H. 2010. Goniothalamin induces coronary artery smooth muscle cells apoptosis: The p53-dependent caspase-2 activation pathway. Toxicological Sciences 116(2): 533-548.

Chen, C., Cao, J., Ma, X., Wang, X., Chen, Q., Yan, S., Zhao, N., Geng, Z. \& Wang, Z. 2016. Neuroprotection by polynitrogen manganese complexes: Regulation of reactive oxygen species- related pathways. Sci. Rep. 6: 20853. doi: 10.1038/ srep20853.

Chew, K.K., Ng, S.Y., Thoo, Y.Y., Khoo, M.Z., Wan Aida, W.M. \& Ho, C.W. 2011. Effect of ethanol concentration, extraction time and extraction temperature on the recovery of phenolic compounds and antioxidant capacity of Centella asiatica extracts. International Food Research Journal 18: 571-578.

Choi, H.N., Chung, M.J., Park, J.K. \& Park, Y. 2013. Neuroprotective effects of $N$-acetylglucosamine against hydrogen peroxide-induced apoptosis in human neuronal SKN-SH cells by inhibiting the activation of caspase-3, PARP and p38. Food Sci. Biotechnol. 22(3): 853-858.

Ezoulin, M.J.M., Ombetta, J.E., Dutertre-Catella, H., Warnet, J.M. \& Massicot, F. 2008. Antioxidative properties of galantamine on neuronal damage induced by hydrogen peroxide in SK-N-SH cells. NeuroToxicology 29(2): 270-277.

Hu, Y., Peng, Y., Long, Y., Xu, S., Feng, N., Wang, L. \& Wang, X. 2012. Potassium 2-(1-hydroxypentyl)-benzoate attenuated hydrogen peroxide-induced apoptosis in neuroblastoma SKN-SH cells. European Journal of Pharmacology 680(1-3): 49-54.

Jayaraj, R.L., Tamilselvam, K., Manivasagam, T. \& Elangovan, N. 2013. Neuroprotective effect of CNB-001, a novel pyrazole derivative of curcumin on biochemical and apoptotic markers against rotenone-induced SK-N-SH cellular model of Parkinson's Disease. J. Mol. Neurosci. 51(3): 863-870.

Jayasinghe, C.J., Gotoh, N., Aoki, T. \& Wada, S. 2003. Phenolics composition and antioxidant activity of sweet basil (Ocimum basilicum L.). J. Agr. Food Chem. 51(15): 4442-4449.

Jin, M.M., Zhang, L., Yu, H.X., Meng, J., Sun, Z. \& Lu, R.R. 2013. Protective effect of whey protein hydrolysates on $\mathrm{H} 2 \mathrm{O} 2$-induced $\mathrm{PC} 12$ cells oxidative stress via a mitochondriamediated pathway. Food Chemistry 141(2): 847-852.

Kasparavičienė, G., Ramanauskienė, K., Savickas, A., Velžienė, S., Kalvėnienè, Z. \& Kazlauskienė, D., Ragažinskienė, O. \& Ivanauskas, K. 2013. Evaluation of total phenolic content and antioxidant activity of different Rosmarinus officinalis L. ethanolic extracts. Biologija. 59(1): 39-44.

Kathirvel, P. \& Ravi, S. 2012. Chemical composition of the essential oil from basil (Ocimum basilicum Linn.) and its in vitro cytotoxicity against HeLa and HEp-2 human cancer cell lines and NIH 3T3 mouse embryonic fibroblasts. Nat. Prod. Res. 26: 1112-1118.

Kaurinovic, B., Popovic, M., Vlaisavljevic, S. \& Trivic, S. 2011. Antioxidant capacity of Ocimum basilicum L. and Origanum vulgare L. extracts. Molecules 16(9): 7401-7414.

Koutroumanidou, E., Kimbaris, A., Kortsaris, A., Bezirtzoglou, E., Polissiou, M. Charalabopoulos, K. \& Pagonopoulou, O. 2013. Increased seizure latency and decreased severity of pentylenetetrazol-induced seizures in mice after essential oil administration. Epilepsy Res. Treat. 2013: 532657. doi: $10.1155 / 2013 / 532657$.
Kumar, G.P. \& Khanum, F. 2012. Neuroprotective potential of phytochemicals. Pharmacogn. Rev. 6(12): 81-90.

Kwee, E.M. \& Niemeyer, E.D. 2011. Variations in phenolic composition and antioxidant properties among 15 basil (Ocimum basilicum L.) cultivars. Food Chem. 128: 10441050.

Lee, J. 2010. Caffeic acid derivatives in dried Lamiaceae and Echinacea purpurea products. J. Funct. Foods 2: 158-162.

Li, G., Zhang, X.X., Lin, L., Liu, X.N., Ma, C.J., Li, J. \& Wang, C.B. 2014. Preparation of ginsenoside Rg3 and protection against $\mathrm{H}_{2} \mathrm{O}_{2}$-induced oxidative stress in human neuroblastoma SK-N-SH cells. Journal of Chemistry. 2014: 848571. http://dx.doi.org/10.1155/2014/848571.

Li, J.K., Liu, X.D., Shen, L., Zeng, W.M. \& Qiu, G.Z. 2016. Natural plant polyphenols for alleviating oxidative damage in man: Current status and future perspectives. Tropical Journal of Pharmaceutical Research May 15(5): 1089-1098.

Naziroğlu, M., Senol, N., Ghazizadeh, V. \& Yürüker, V. 2014. Neuroprotection induced by $\mathrm{N}$-acetylcysteine and selenium against traumatic brain injury-induced apoptosis and calcium entry in hippocampus of rat. Cell. Mol. Neurobiol. 34(6): 895-903.

Patil, D.D., Mhaske, D.K. \& Wadhawa, G.C. 2011. Antibacterial and antioxidant study of Ocimum basilicum Labiatae (sweet basil). J. Adv. Pharmacy Educ. Res. 2: 104-112.

Peng, L., Wang, B. \& Ren, P. 2005. Reduction of MTT by flavonoids in the absence of cells. Colloids and Surfaces B: Biointerfaces 45(2): 108-111.

Rameshrad, M., Salehian, R., Fathiazad, F., Hamedeyazdan, S., Garjani, M. \& Maleki-Dizaji, N. 2015. The effects of Ocimum basilicum ethanol extract on carrageenan induced paw inflammation in rats. Pharm. Sci. 20: 149-156.

Reiter, R.J. 1995. Oxidative processes and antioxidative defense mechanisms in the aging brain. The Federation of American Societies for Experimental Biology 9: 526-533.

Shoemaker, M., Cohen, I. \& Campbell, M. 2004. Reduction of MTT by aqueous herbal extracts in the absence of cells. Journal of Ethnopharmacology 93(2-3): 381-384.

Srivastava, H.C., Shukla, P., Tripathi, S. \& Shanker, B. 2014a. Antioxidant and antimicrobial activities of sweet basil oils. Int. J. Pharm. Sci. Res. 5: 279-285.

Srivastava, S., Cahill, D.M., Conlan, X.A. \& Adholeya, A. 2014b. A novel in vitro whole plant system for analysis of polyphenolics and their antioxidant potential in cultivars of Ocimum basilicum. J. Agr. Food Chem. 62(41): 10064-10075.

Steinbrenner, H. \& Sies, H. 2013. Selenium homeostasis and antioxidant selenoproteins in brain: Implications for disorders in the central nervous system. Arch. Biochem. Biophys. 536(2): 152-157.

Sultana, B., Anwar, F. \& Ashraf, M. 2009. Effect of extraction solvent/technique on the antioxidant activity of selected medicinal plant extracts. Molecules 14(6): 2167-2180. doi:10.3390/molecules 14062167

Yang, H., Dong, Y., Du, H., Shi, H., Peng, Y. \& Li, X. 2011. Antioxidant compounds from propolis collected in Anhui, China. Molecules 16(4): 3444-3455. doi:10.3390/ molecules16043444.

Yu, B.W., Li, J.L., Guo, B.B., Fan, H.M., Zhao, W.M. \& Wang, H.Y. 2016. Chlorogenic acid analogues from Gynura nepalensis protect $\mathrm{H} 9 \mathrm{c} 2$ cardiomyoblasts against $\mathrm{H}_{2} \mathrm{O}_{2}-$ induced apoptosis. Acta Pharmacologica Sinica 37: 14131422 . 
Zgorka, G. \& Glowniak, K. 2001. Variation of free phenolic acids in medicinal plants belonging to the Lamiaceae family. $J$. Pharmaceut. Biomed. Anal. 26(1): 79-87.

Zhang, J.X., Wang, R., Xi, J., Shen, L., Zhu, A.Y., Qi, Q., Wang, Q.Y., Zhang, L.J., Wang, F.C., Lü, H.Z. \& Hu, J.G. 2017. Morroniside protects SK-N-SH human neuroblastoma cells against $\mathrm{H}_{2} \mathrm{O}_{2}$-induced damage. International Journal of Molecular Medicine 39(3): 603-612.

Zongo, C., Savadogo, A., Ouattara, L., Bassole, C.A., Ouattara, A.S., Barro, N., Koudou, J. \& Traore, A.S. 2010. Polyphenols content, antioxidant and antimicrobial activities of Ampelocissus grantii (Baker) Planch. (Vitaceae): A medicinal plant from Burkina Faso. International Journal of Pharmacology 6(6): 880-887.

Manali Haniti Mohd-Zahid, Juriyati Jalil \& Norazrina Azmi* Drug and Herbal Research Centre

Faculty of Pharmacy

Universiti Kebangsaan Malaysia

Jalan Raja Muda Abdul Aziz

50300 Kuala Lumpur, Federal Territory

Malaysia
Kok Meng Chan

Toxicology Laboratory

Faculty of Health Sciences

Universiti Kebangsaan Malaysia

Jalan Raja Muda Abdul Aziz

50300 Kuala Lumpur, Federal Territory

Malaysia

*Corresponding author; email: azrina.azmi@ukm.edu.my

Received: 4 March 2018

Accepted: 14 May 2018 